\title{
THE GEOGRAPHICAL DISTRIBUTION OF THE PREVALENCE AND MORTALITY OF LUNG CANCER IN ROMANIA
}

DOI: http://dx.doi.org/10.18509/GBP.2019.56

UDC: 314.14:616-006-.036.8(498)

\author{
Iulia Daniela Nedelcu ${ }^{1,2}$ \\ Adrian Gabriel Simion 1,2 \\ Marian Marin 1,2 \\ Alisa Predescu 1,2 \\ Daniel Peptenatu 1,2 \\ ${ }^{1}$ University of Bucharest - Faculty of Geography, Bucharest, Romania. \\ ${ }^{2}$ Research Centre for Integrated Analysis and Territorial Management, Bucharest, Romania.
}

\begin{abstract}
Cancer is a global problem, until recently cardiovascular disease occupies the 1 st place as importance in the illness of the population, but for several years, according to the United Nations, it is becoming the most important public health issue. According to the International Agency for Research on Cancer, 1,825 million cases of lung cancer were estimated globally in 2012, respectively $13 \%$ of all cancer cases and 1.59 million deaths due to this type of cancer (19.4\% from the total deaths). In this article are presented the trends of lung cancer in oncology prevalence and mortality in Romania. The research is based on the existence of medical data on the incidence of cancer in Romania for the period 2008-2017, before the accession to the European Union, these data are considered irrelevant due to the wrong ways of collecting. Afterwards, these data are classified and reported to the territorial administrative units, then statistical analyzes, spatial and fractal modeling are performed. The results obtained show the concentration of lung cancer in urban systems and old industrial areas.
\end{abstract}

Keywords: Cancer, lung cancer, oncological mortality, spatial modeling.

\section{INTRODUCTION}

Cancer is considered the leading cause of death in economically developed countries due to population aging and growth [1], [2], and one of the main problems of population mortality in developing countries [3]. According to the World Health Organization, 1 in 6 deaths is the result of cancer with 9.6 million deaths in 2018. In 2008, 12.7 million cases of cancer were recorded globally and 7.6 million deaths, of which $56 \%$, respectively $64 \%$ of cases and deaths occurred in large economically developed areas [4]. From the total cancer cases, among the female population, the most common type of cancer and the cause of death is breast cancer (23\% of illnesses, $14 \%$ of deaths), and among the male population, lung cancer occupies extreme values for both illnesses and death (17\% of illnesses, $23 \%$ of deaths) [2]. In 2012, the situation is changing, there are 14.1 new cases of cancer and 8.2 million deaths, and lung cancer is the most common type of cancer, 1.82 million [5].

What causes lung cancer to be one of the main causes of oncological mortality is primarily symptomatology that often is not present [6], [7], [8], therefore, finding the diagnosis of this type of cancer is done late, even in terminal stages or treatment options are limited or 
even non-existent. Therefore, global oncology mortality places lung cancer on the third place after breast cancer and prostate cancer [9].

The use of healthcare directly related to geography can generate extraordinary results in the development of general medical infrastructure from the medical monitoring sector. National public health objectives aim at increased the use of the GIS technologies, making investments more cost-effective by reducing costs [10]. The use / analysis of medical data on a larger scale, was possible with the evolution of technology and the introduction of new approaches to the use of GIS analyzes and methods, which allowed the use of a huge amount of data that was hard to process in the past. The use of GIS technologies allows the data to be processed in order to make spatial models useful in the development of public policies [11], [12], [13]. Medical records of the population are described as defining tools in conducting a cancer-based study, using GIS technology, but there have been political, economic or medical elements, especially in developing countries, which prevented the implementation of technologies to the desired level [14], [15].

\section{METHODOLOGY}

\section{Study area}

The analysis of lung cancer was performed according to the national coverage database reported to the territorial administrative units of Romania (3181 territorial administrative units) for the period 2008, after Romania's accession to the European Union, when the responsible institutions centralized all these data and until 2017; oncology mortality was analyzed for the period 2008-2016.

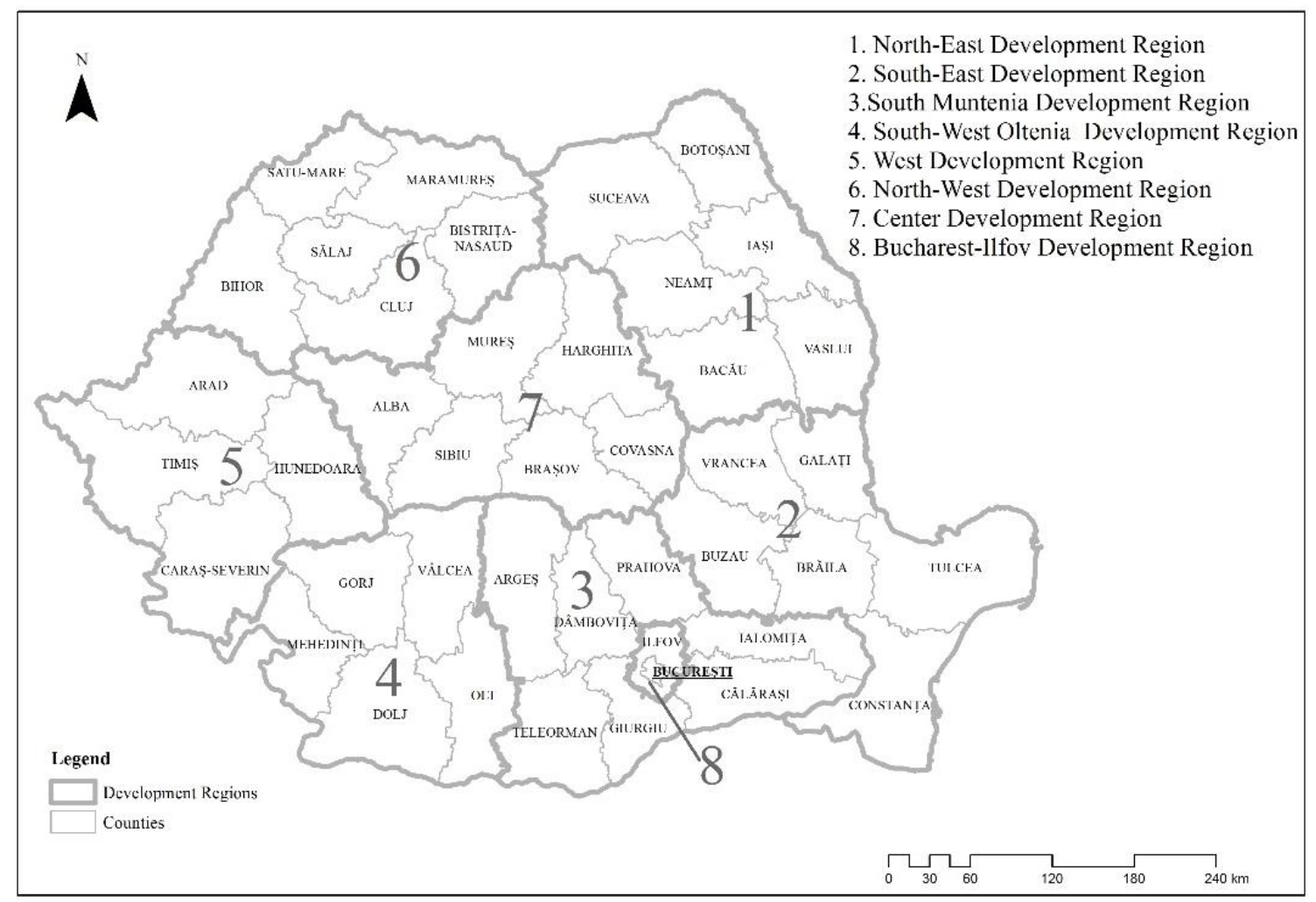

Figure 1. Study area. Development regions and counties of Romania 


\section{Spatial modeling of oncological prevalence}

\section{and mortality for bronchial and lung malignant tumors (C34)}

The total male and female cancer prevalence (C00-C95) was calculated from primary medical data, subsequently processed and represented as a database. The processing of medical data implied the aggregation of all types of tumors according to the international classification at the territorial administrative unit level in order to be subsequently loaded into GIS specific software, from which the spatial distributions of tumors resulted, for this study the distribution of lung cancer (C34). The database was used with the RDBMSPostgreSQL database relational system where the data were aggregated and pivoted to support various statistical situations. The database contains a huge number of recordings, so the processing time can be quite long, this especially depending on the hardware component. The resulting statistical situations were exported as a Microsoft Excel compatible table, that allows you to create graphics or interpretations, specific to the data type or allows different interpretations. The spatial distribution was done in a Gis opensource software, QuantumGis, which allows connection to the previously created database at the locality level based on the SIRUTA code (Information System of the Register of Territorial - Administrative Units).

Depending on the resulting tables, reported to the territorial administrative unit, classification is made according to the prevalence values for each year of the interval. The classification was done in 4 classes represented in grayscale, the high values being represented by lighter shades and the smaller ones with darker shades. Thus, 30 maps with the prevalence of lung cancer in Romania for total, male and female in 2008-2017 were created and 27 cartographic models with the mortality situation caused by this type of cancer for the period 2008-2016.

\section{RESULTS}

\section{Prevalence of bronchial and lung malignant tumors (C34) in Romania}

Following the analysis of the three figures (Figure 2, Figure 3, Figure 4), we have estimated that the trend of extreme values is to be kept in the same areas, as in the case of small values. Both counties and development regions can be found in Figure 1.

In figure 2 we can see that the maximum values exceeding the threshold of 201 cases of illness, are present in the urban area, in cities such as Bucharest, where the most cases of lung cancer are registered (about 3,400 cases in 2008 and 2,800 in the final year analyzed), followed by Piteşti (Argeş County), Craiova (Dolj County), Timişoara (Timiş County) and others. Regarding the minimum values, under 50 cases, localities such as Ciuperceni (Teleorman County), Vişina Nouă (Olt County), Cioroiaşi (Dolj county) and many other rural localities, predominantly located in the south of the country. Figure 3 shows the situation of the geographical distribution of the prevalence of malignant tumors (C34) of the female population. The highest values, over 101 cases, are recorded in major cities, Bucharest (952 cases in 2017), Ploiesti (Prahova county) with values that have decline significantly since 2008 in 2017, from 125 to 60 cases, Timisoara (Timis County), etc. The lowest recorded values are also found in rural areas such as Ciuperceni (Teleorman County), Gura Padinei (Olt County), Malu (Giurgiu). The geographical distribution of the prevalence of malignant tumors of the lungs (C34) among the male population (Figure 4) shows values over 101 cases in Bucharest (from about 2,500 diseases to 1,800 in 2017), Pitesti (Arges County) with a downward trend from 600 cases at 160 cases in 2017, Craiova (Dolj County) and other large urban centers. Small values retain their location in 
rural areas, Goicea (Dolj County), Izlaz (Olt County), etc., throughout the analyzed period. We can notice that the highest values, regardless of the female or masculine population, are recorded in the big, polluted urban centers.

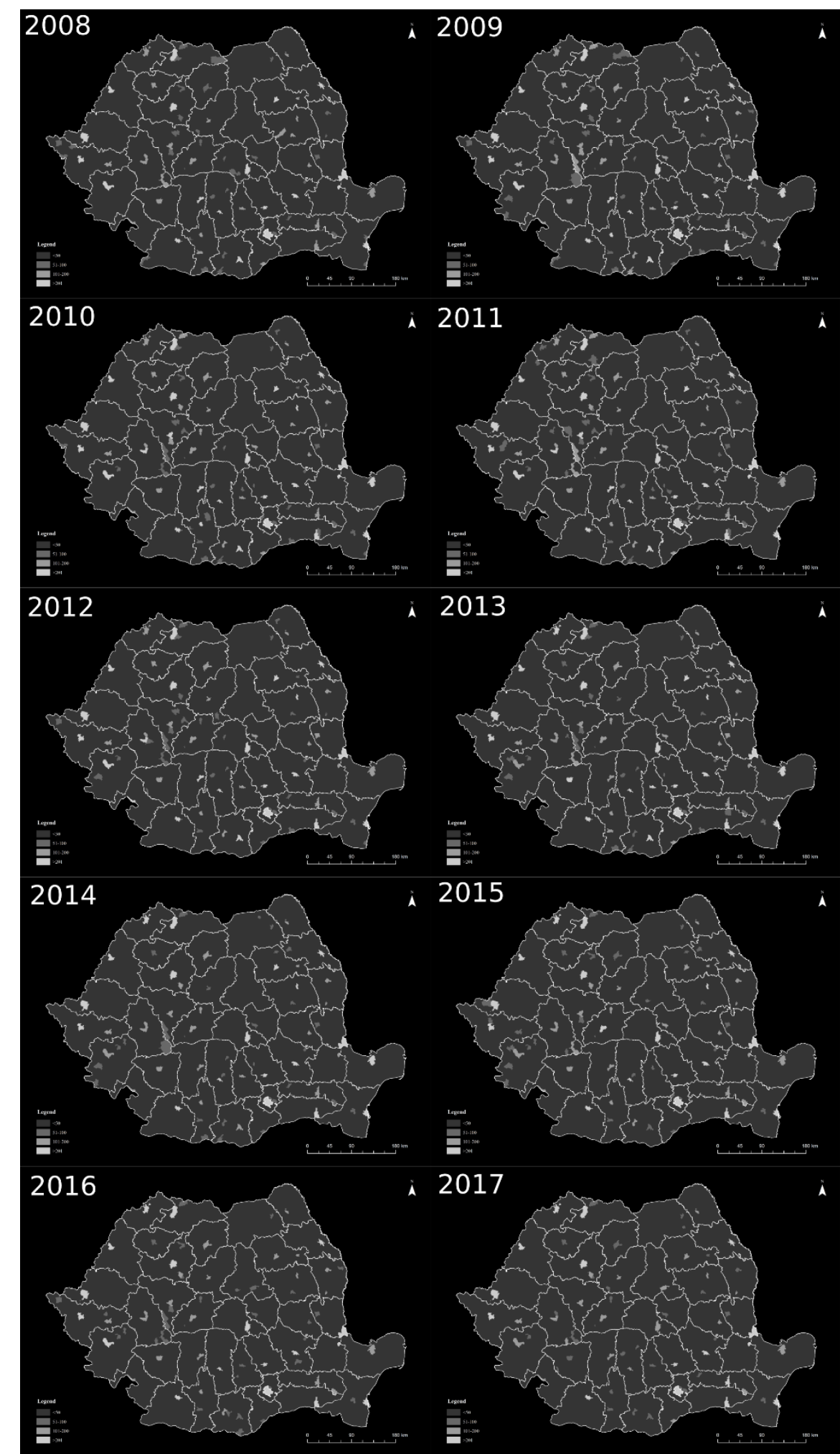

Figure 2. Geographical distribution of malignant tumors (C34) -total (persons). Source: Ministry of Health 


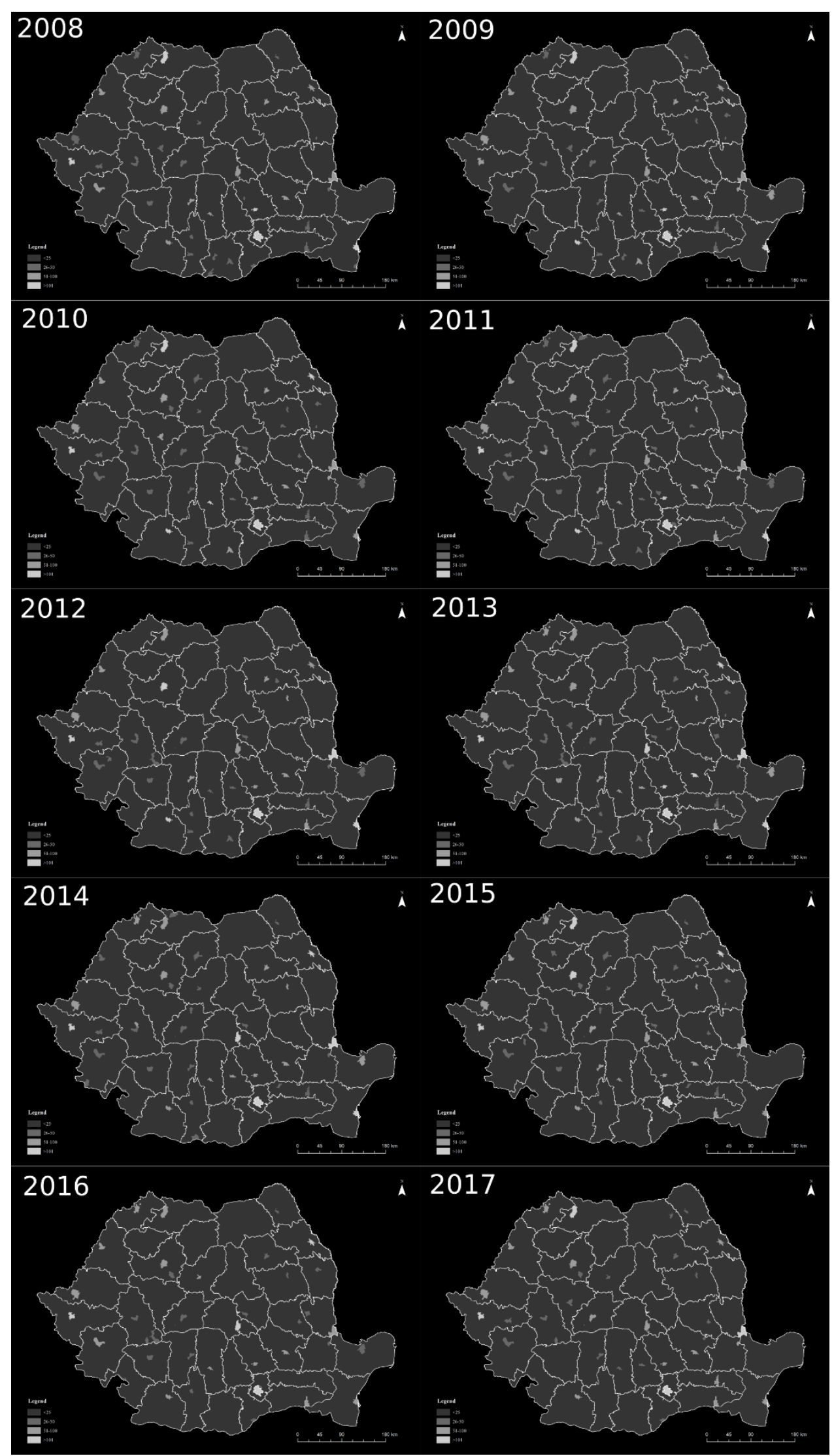

Figure 3. Geographical distribution of malignancy (C34) -female (persons) tumors prevalence. Source: Ministry of Health 


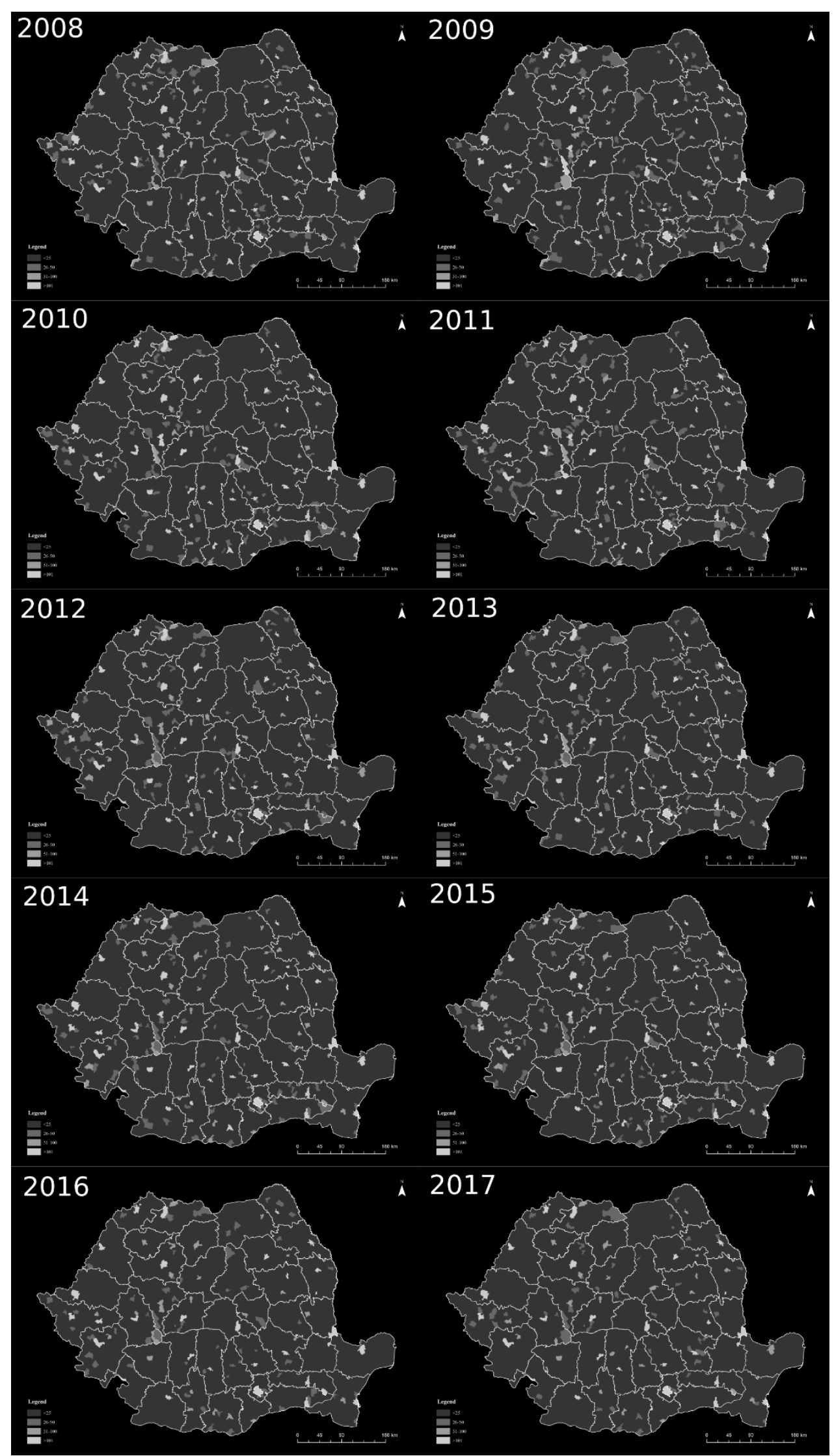

Figure 4. Geographical distribution of malignancy (C34) -male (persons) tumors prevalence. Source: Ministry of Health 


\section{Oncological mortality in Romania for the period 2008-2016}

In the second part of the study, we wanted to see what happened to all those cases of illness, more exactly, how many deaths are recorded due to this type of cancer, where are located most of the values and where the smallest are found and what are the trends. Thus, in Figure 5 we have the geographical distribution of total oncological mortality due to lung or bronchial diseases, divided into 4 classes for a period of 9 years, 2008-2016. The highest values, over 101 deaths, are recorded in Constanta (Constanta County), Timisoara (Timis County) with 104 cases in 2008 and 226 in 2016 and with a total of 9 years more than 500 deaths; the city of Bucharest sums up 750 deaths during this period. Less than 10 deaths were recorded in settlements in the south of the country such as Găujani (Giurgiu), Spanţov (Călăraşi County), Sfinteşti (Teleorman County), etc. As for the female population (Figure 6), the highest values of more than 51 deaths are recorded in Timişoara (Timiş county) with a total of 386 deaths, Cluj Napoca (Cluj County), Iaşi (Iaşi County), Bucharest 27 deaths in 2016 and other localities in the urban area. Localities with less than 5 deaths due to lung cancer are present both in rural and urban areas, Calafat (Dolj County), Baileşti (Dolj), Urzica (Olt County), etc. Figure 7 shows the oncological mortality of the male population due to lung or bronchial conditions (C34), and the highest values are recorded in Constanta (Constanta County), Timisoara (Timis County), Bucharest and other localities that exceed the threshold of 51 deaths per year. The lowest values are present in rural areas, in the localities: Teaca (Bistrita-Nasaud County), Saveni (Botosani County), Sambata (Bihor County), etc.

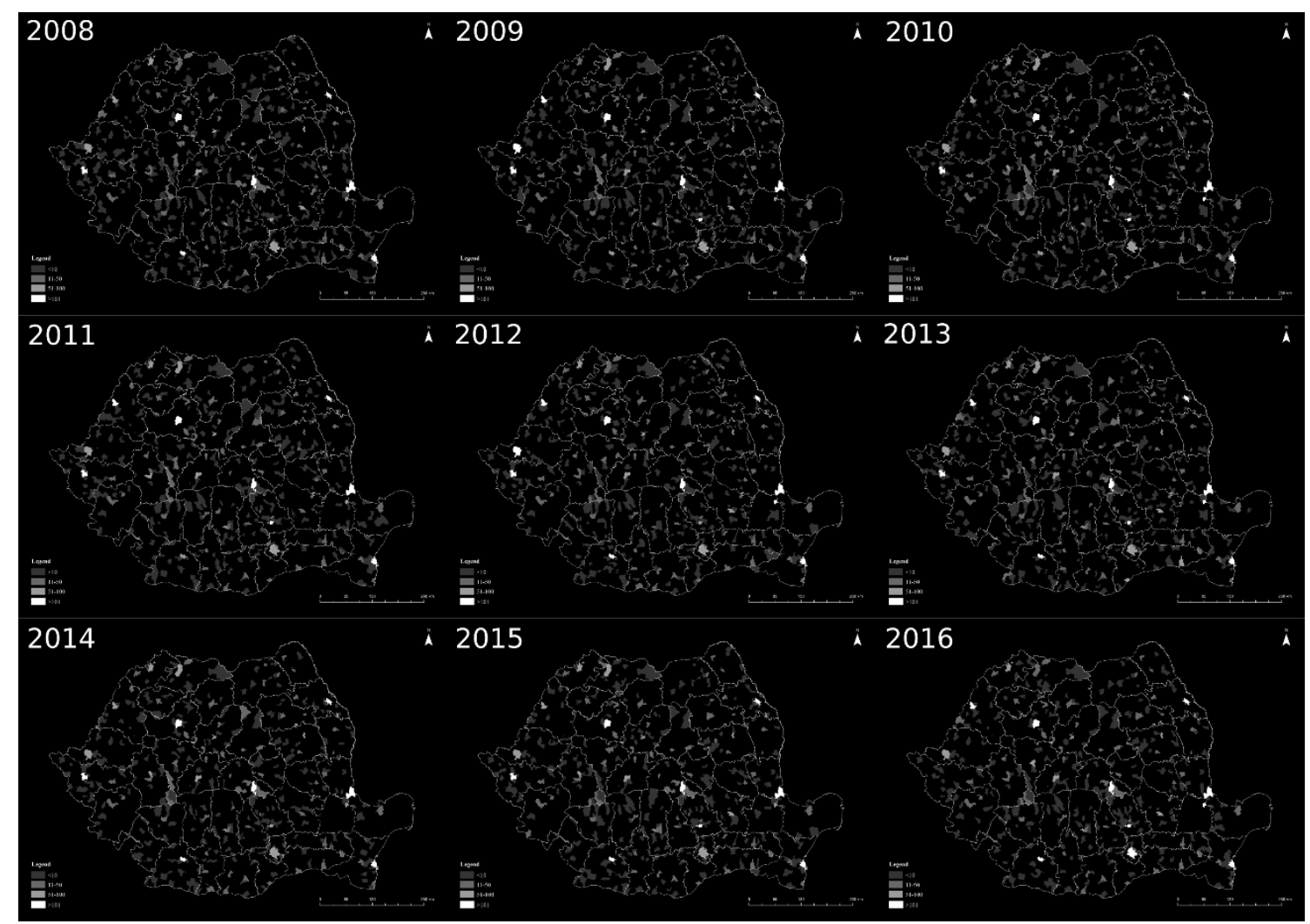

Figure 5. Geographical distribution of oncological mortality (C34) -total (persons). Source: Ministry of Health 


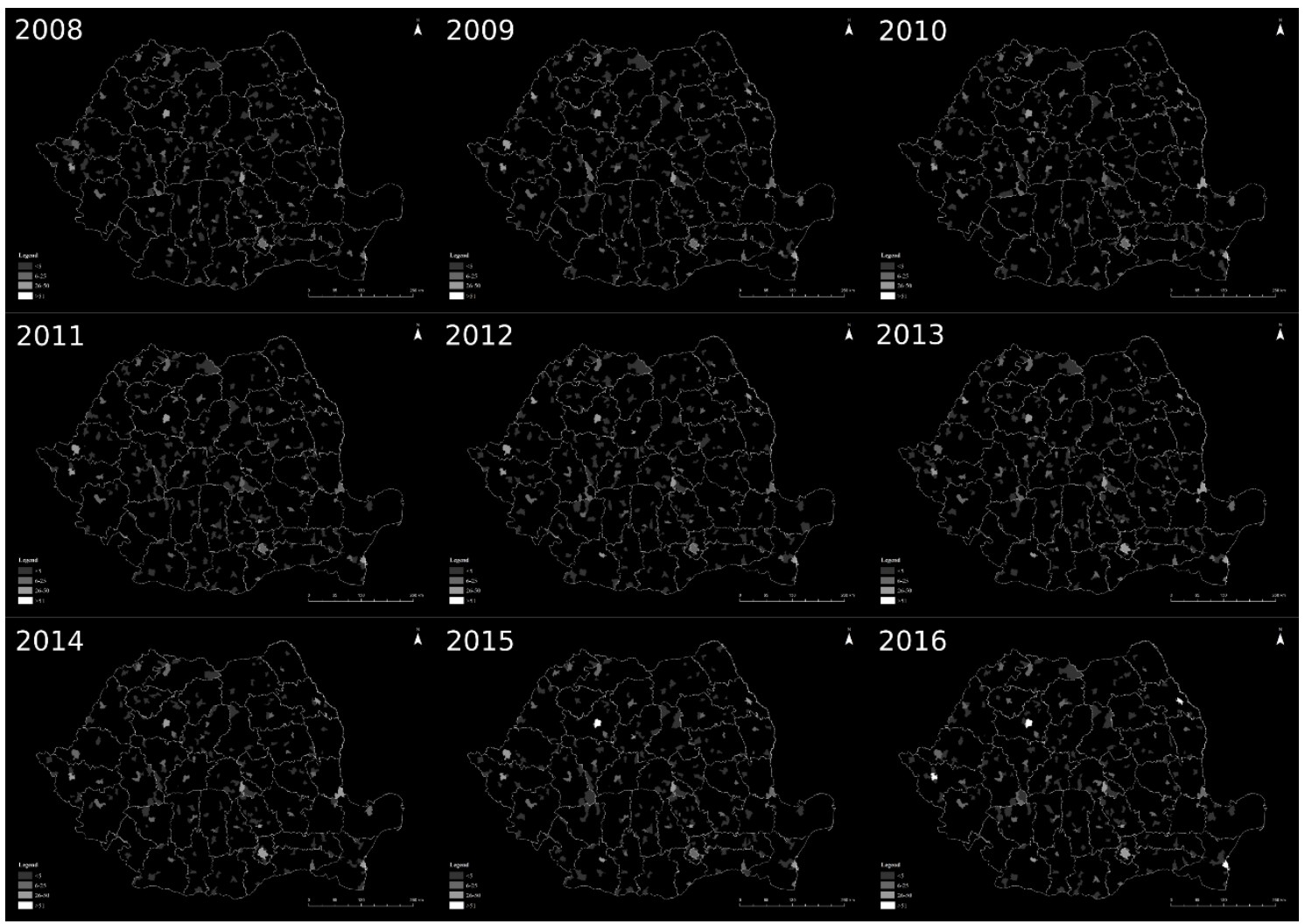

Figure 6. Geographical distribution of oncological mortality (C34)- female (persons). Source: Ministry of Health

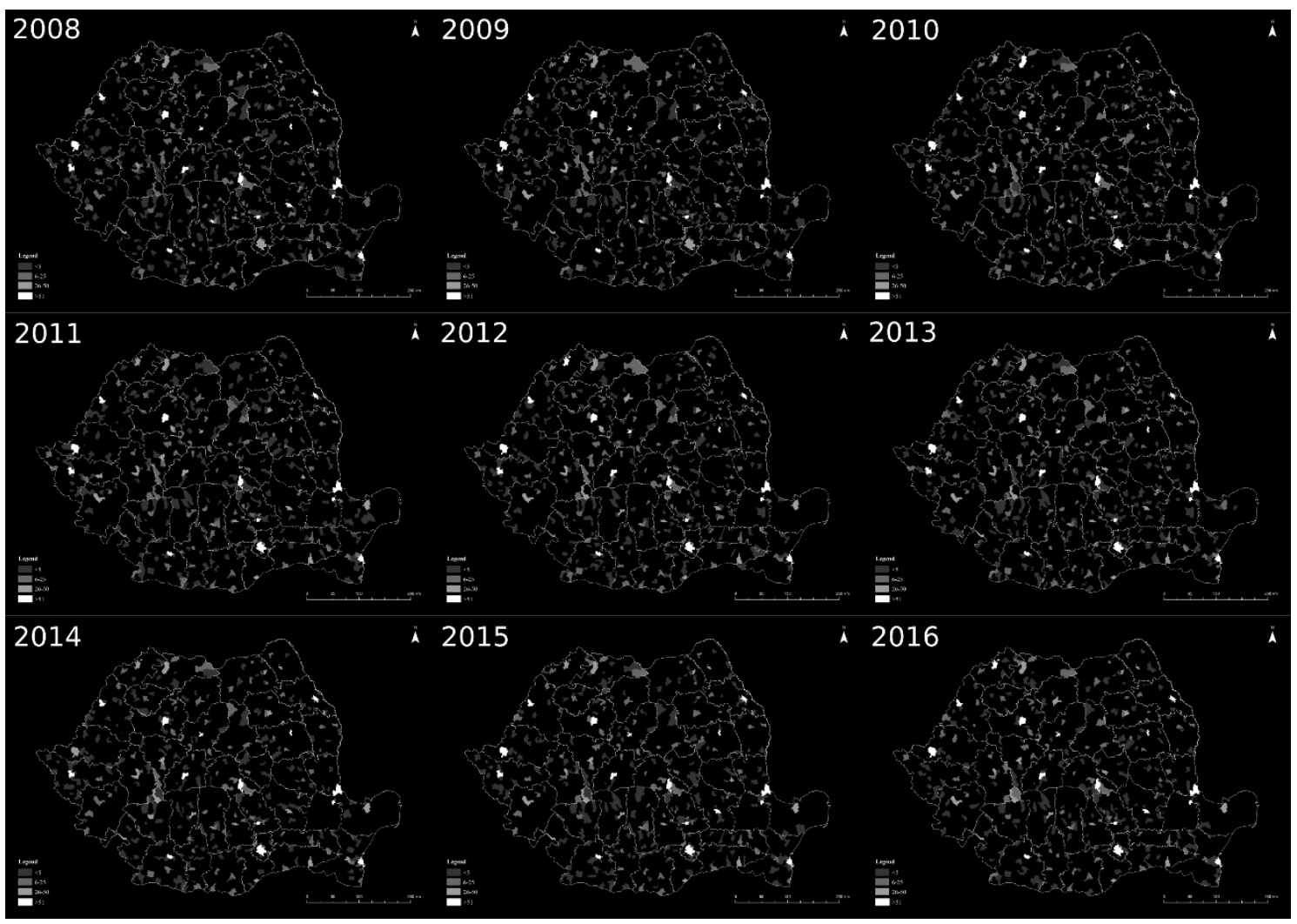

Figure 7. Geographical distribution of oncological mortality (C34) -male (persons).

Source: Ministry of Health 


\section{CONCLUSIONS}

Among the main factors responsible for lung cancer are the emissions of harmful substances from homes, industry and, last but not least, from vehicles, which, according to the World Health Organization, represents $25-40 \%$ of total emissions. The highest values are recorded in the major cities, Bucharest, Ploiesti, Timisoara, and the lowest recorded values are found in rural areas such as Ciuperceni (Teleorman County), Gura Padinei (Olt County), Malu (Giurgiu). The geographical distribution of the prevalence of lung cancer in the male population shows high values in Bucharest, from about 2,500 diseases to 1,800 in 2017), Pitesti (Argeş County) with a downward trend, Craiova (Dolj county) and other large urban centers. Small values retain their location in rural areas, Goicea (Dolj County), Izlaz (Olt County), etc., throughout the analyzed period. Regarding the development regions, most cases of cancer, for the 10 years analyzed, were recorded in the South Muntenia region, with 4,815 cases only in 2017 and a total of 60,708 cases, followed by the North-East region with a total of 44,925 illnesses. At the level of development regions, most lung cancer deaths, for the 9 years analyzed, are found in the South East region, about 6,000 deaths and the North-East region with a total of 5,300 deaths.

The results obtained can contribute to a better understanding of the way in which the territorial systems affected by anthropogenic action respond, aspects researched in many specialized studies [16], [17], [18], [19], [20], [21], [22], [23], [24].

\section{REFERENCES}

[1] Torre, L. A, Bray, F., Siegel, R. L., Ferlay, J., Lortet-Tieulent, J., Jemal, A. Global Cancer Statistics, 2012, CA A Cancer Journal for Clinicians, 2015, pp 87-108;

[2] Jemal, A., Bray, F., Center, M. M., Ferlay, J., Ward, E., Forman, D. Global Cancer Statistics, CA A Cancer Journal for Clinicians, 2011, pp 69-90;

[3] World Health Organization. The Global Burden of Disease: 2004 Update. Geneva:World Health Organization; 2008;

[4] Ferlay, J., Shin, H.-R., Bray, F., Forman, D., Mathers, C., Parkin, D. M. Estimates of worldwide burden of cancer in 2008: GLOBOCAN 2008, International Journal of Cancer, 2010, pp 2893-2917;

[5] Ferlay, J., Soerjomataram, I., Dikshit,R., Eser, S., Mathers, C., Rebelo, M., Parkin, D. M., Forman, D., Bray, F. Cancer incidence and mortality worldwide: Sources, methods and major patterns in GLOBOCAN 2012, International Journal of Cancer, 2015, pp 359-386;

[6] Al-Ahmadi, K., Al-Zahrani, A. S. Spatial autocorrelation of cancer incidence in Saudi Arabia, International Journal of Environmental Research and Public Health, 2013, pp 7207-7228;

[7] Bhatt, S, Gething, P. W., Brady, O. J., Messina, J. P., Farlow, A. W., Moyes, C. L., Drake, J. M., Brownstein, J. S., Hoen, A. G., Sankoh, O., Myers, M. F., George, D. B., Jeenisch, T., Wint, G. R., Simmons, C. P., Scott, T. W., Farrar, J. J., Hay, S. I. The global distribution and burden of dengue, Nature, 2013, pp 504-507;

[8] Hassarangsee, S., Tripathi, N. K., Souris, M. Spatial pattern detection of tuberculosis: A case study of Si Sa Ket Province, Thailand, International Journal of Environmental Research and Public Health, 2015, pp 16005-16018;

[9] Siegel, R., Naishadham, D., Jemal, A. Cancer Statistics, 2013, CA A Cancer Journal for Clinicians, 2013, pp 11-30;

[10] American Cancer Society. Cancer Facts and Figures 2015. https://www.cancer.org/ 
[11] Hay, S. I., George, D. B., Moyes, C. L., Brownstein, J, S. Big Data Opportunities for Global Infectious Disease Surveillance, Plos Medicine, 2013;

[12] Salathé, M. Digital epidemiology: what is it, and where is it going? Life Sciences, Society and Policy, 2018;

[13] Salathé, M. Bengtsson, L, Bodnar, T.J., Brewer, D.D., Brownstein, J. S., Buckee, C., Campbell, E. M., Cattuto, C., Khandelwal, S., Mabry, P. L., Vespignani, A. Digital epidemiology, Plos Computational Biology, 2012, pp ;

[14] Allemani, C., Weir H. K., Carreira, H., Harewood, R., Spika, D., Wang, X. S., et al. Global surveillance of cancer survival 1995-2009: Analysis of individual data for 25676887 patients from 279 population-based registries in 67 countries (CONCORD-2), Lancet, 2015, pp 977-1010;

[15] Jones, L., Chilton, J., Hajek, R., Iammarino, N., Laufman, L. Between and within: International perspectives on cancer and health disparities, Journal of Clinical Oncology,2016, pp 2204-2208;

[16] Pintilii, R. D., Andronache, I., Diaconu, D. C., Dobrea, R. C., Zelenakova, M., Fensholt, R., Peptenatu, D., Draghici, C. C., Ciobotaru, A. M. Using Fractal Analysis in Modeling the Dynamics of Forest Areas and Economic Impact Assessment: Maramures County, Romania, as a Case Study, Forests, 2017 vol. 8;

[17] Peptenatu, D., Merciu, C., Merciu, G., Drăghici C., Cercleux, L. Specific features of environment risk management in emerging territorial structures, Carpathian Journal of Earth and Environmental Sciences, 2012 vol. 7, pp 135-143;

[18] Andronache, I., Ahammer, H., Jelinek, H. F., Peptenatu, D., Ciobotaru, A. M., Drăghici, C. C., Pintilii, R. D., Simion, A. G., Teodorescu, C. Fractal analysis for studying the evolution of forests, Chaos Solitons \& Fractals, 2016, vol. 91, pp 310-318;

[19] Pintilii, R. D., Andronache, I., Simion, A. G., Drăghici, C. C., Peptenatu, D., Ciobotaru, A. M., Dobrea, R. C., Papuc, R. M. Determining forest fund evolution by fractal analysis (SuceavaRomania), Urbanism Architecture Constructions, 2016, vol. 7, pp 31-42;

[20] Drăghici, C. C., Peptenatu, D., Simion, A. G., Pintilii, R. D., Diaconu, D. C., Teodorescu, C., Papuc, R. M., Grigore, A. M., Dobrea, C. R. Assessing economic pressure on the forest fund of Maramures County - Romania, Journal of Forest Science (Prague), 2016, vol. 62, pp 175-185;

[21] Drăghici, C. C., Andronache, I., Ahammer, H., Peptenatu, D., Pintilii, R. D., Ciobotaru, A. M., Simion, A. G., Dobrea, R. C., Diaconu, D. C., Vișan, M. C., Papuc R. M. Spatial evolution of forest areas in the northern Carpathian Mountains of Romania, Acta Montanistica Slovaca,2017, vol. 22, pp 95-106;

[22] Da Silva, P. R. B., Makara, C. N., Munaro, A. P., Schnitzler, D. C., Diaconu, D. C., Sandu, I., Poleto, C. Risks Associated of the Waters from Hydric Systems Urban's The case of the rio Barigui, south of Brazil, REVISTA DE CHIMIE, 2017, vol 68, pp 1834-1842;

[23] Diaconu, D. C., Andronache, I., Ahammer, H., Ciobotaru, A. M., Zelenakova, M., Dinescu, R., Pozdnyakov, A. V., Chupikova, S. A. Fractal drainage model - a new approach to determinate the complexity of watershed, ACTA MONTANISTICA SLOVACA, 2017, vol 22, pp 12-21;

[24] Zelenakova, M., Ganova, L., Purcz, P., Horsky, M., Satrapa, Blistan, P., Diaconu, D. C. Mitigation of the Adverse Consequences of Floods for Human Life, Infrastructure, and the Environment, NATURAL HAZARDS REVIEW,2017, vol 18. 